\title{
Nutritional composition, assessed by chemical analyses, of prepared foods available for primary-school children: a comparison of public and private schools
}

\author{
Márcia L Weber ${ }^{1,2}$ and Tania B Morais ${ }^{2, *}+$ \\ 'Department of Nutrition, University of Alfenas, Alfenas, MG, Brazil: ${ }^{2}$ Food Quality Control Laboratory, \\ Federal University of São Paulo, São Paulo, SP, Brazil
}

Submitted 14 September 2009: Accepted 10 February 2010: First published online 21 April 2010

\begin{abstract}
Objective: To assess the nutritional quality of prepared foods available to primaryschool children.

Design: Prepared foods available in a public and private school were sampled daily for 4 weeks (a total of forty-five samples) and chemically analysed for protein, fat, carbohydrate, iron, salt and sodium. The results were compared to the nutritional standards for children aged 7-10 years.

Setting: Alfenas, south-eastern Brazil.

Results: The concentration of protein, lipid, iron and sodium and the energy values of the foods at the private school were significantly higher than those at the public school. No differences were seen in the carbohydrate and salt values. The range of macronutrients was more balanced at the public school in relation to fat and protein. Foods at the private school were, in general, energy-dense. At both the public and private school, they provided the minimum energy and iron. Salt content was over twice the maximum amount, and that for sodium was over three times the amount, in both the public and private school.

Conclusions: Overall, foods prepared at the public school were better nutritional quality than those at the private school and those offered in public schools in some developed countries. This finding can probably be explained by the fact that a nutritionist, as required by law, was responsible for planning the menus at the public school. However, corrective action is needed to adjust for the wide variability in energy and nutrient content during weekdays and in the sodium content of prepared foods available in both the public and private school.
\end{abstract}

\author{
Keywords \\ School feeding \\ Food composition
}

In Brazil, the School Meals Programme originated in the early 1940s, when the federal government proposed legislation to provide school meals. However, a lack of funds meant that implementation of the proposals was postponed until 1955. Since then, the Brazilian federal government has transferred funds to states and cities to subsidise local programmes. All children enrolled in daycare centres, pre-schools and those in the compulsory schooling period in public and non-profit-making private schools are eligible for free meals. The Programme requires that school meals provide $15 \%$ of the child's daily nutritional requirements, but decisions about specific foods are made by local school food authorities. Today, the Brazilian Programme has more than 30 million children enrolled and is considered to be one of the largest and most comprehensive in the world ${ }^{(1)}$. Because of

$\dagger$ Correspondence address: Tania Beninga Morais, R. dos Otonis, 880 apto. 63, 04025-901 São Paulo, SP, Brazil. their widespread availability, school meals programmes are in a unique position to influence the nutritional quality of children's diets and their food choices on a daily basis, and potentially contribute to the development of healthy dietary habits and preferences ${ }^{(2,3)}$. No other institution has as much continuous and intensive contact with children ${ }^{(3)}$. Consumption of school meals was positively related to children's intake of key healthy food groups for participants in the US National School Lunch Program (NSLP) ${ }^{(4)}$. Nevertheless, there was an association between programme participation and excessive sodium intake, along with a high prevalence of excessive saturated fat intake ${ }^{(5)}$.

All these previous studies relied on food composition tables rather than on chemical analysis. Because of financial constraints, developing countries often borrow data from tables used by developed countries, particularly the US Department of Agriculture's food composition tables, and incorporate them into their own food 
composition tables. However, such a practice can be questioned, considering that foods naturally vary in their composition $^{(6)}$. A Brazilian study using 700 processed food samples showed that there were statistical differences between the data obtained from laboratory investigations and food composition tables ${ }^{(7)}$. In addition, differences in composition of prepared foods can arise from differences in the amounts of ingredients used and the processing or cooking conditions ${ }^{(6)}$.

Few studies have been carried out on the nutritional quality of school meals based on chemical analyses ${ }^{(8)}$. We were unable to find any studies in the literature on the nutritional composition of foods available at private schools. Thus, the aim of the present exploratory study was to assess the nutritional quality of foods available to primary-school children by comparing foods prepared under the guidelines of the Brazilian School Meals Programme at public schools to the nutritional quality of foods prepared and sold at private schools. Macronutrients, energy, iron, sodium and salt were also compared with nutrient standards to identify potential nutritional shortcomings.

\section{Methods}

The present study was conducted during the summer of 2007 according to the guidelines laid down in the Declaration of Helsinki, and all procedures involving participants were approved by the Ethics Committees of the Federal University of São Paulo and University of Alfenas. Written informed consent was obtained from all parents. Verbal consent from all children was witnessed and formally recorded.

The city of Alfenas, Brazil has a population of 67000 inhabitants, most of whom live in urban areas. Its Human Development Index was 0.829 in $2000^{(9)}$. It has three private schools and twelve public schools in its central area. From these, the authors chose a convenient sample of one public school with the largest number of primary-school students. As the researchers had no legal right of entry into the private schools, the cooperation of the owners was essential, and it was possible to assess only one private school. This private school had the largest number of primary-school students. Of the 805 children eligible to be included in the study, 511 completed the survey on the frequency of consumption of foods available at school. In all, $77 \%$ (304 out of 395) of the students at the public school consumed foods from the school meals programme at least three times a week. At the private school, 53\% (61 out of 116) of the students consumed foods available at school at least three times a week. Children in Brazil attend school $4-5 \mathrm{~h} / \mathrm{d}$ on weekdays.

\section{Sampling}

As required by Brazilian legislation ${ }^{(10)}$, a nutritionist from the city's Department of Education defined the monthly menu planning and the portion sizes that were followed by all public schools. Portion sizes were the same for all children aged 7-10 years. Wastage was also observed and the weight estimated visually. A method of duplicate food collection was used for sampling. Samples of the meals were taken each day for 4 weeks to incorporate all the foods served in a month. Staple foods consisted of rice, beans, ground beef, egg, pasta, potato, cassava flour and corn flour, sausage, vegetables, tomato sauce, milk, banana, salt cookie, chocolate milk and guava jelly. For nutrient analyses, these foods were combined into six basic meals: (i) rice, beans, vegetables, meat and dessert; (ii) rice, vegetables and meat; (iii) pasta, meat and dessert; (iv) polenta and beans; (v) rice pudding; and (vi) chocolate milk and salt cookie. All the foods in meals served to the children were sampled and combined into a single sample, totalling twenty samples ( 4 weeks $\times 5 \mathrm{~d}$ ) for chemical analyses. Children in public school were eligible for free meals; however, there was a cafeteria where children willing to pay could buy soft drinks, candies and fruit-flavoured drinks. These foods were not sampled.

At the private school, a small cafeteria provided sandwiches and snacks. From these, the five foods most often chosen (chicken sfiha; ham and cheese sandwich; pizza; chicken skewer; hot dog) were sampled for chemical analyses, totalling twenty-five samples (five samples of each type of food).

\section{Chemical analyses}

The samples were transported to the laboratory and analysed for moisture, protein, fat, iron, ash and sodium chloride $^{(11)}$. Moisture content was obtained by heating the samples to $102^{\circ} \mathrm{C}$ until a constant weight was attained. Protein level was obtained by determining Kjeldahl nitrogen and multiplying this by $6 \cdot 25$. After acid hydrolysis the fat was extracted with ether using a Soxhlet apparatus. Ash was obtained by incineration at $500-550^{\circ} \mathrm{C}$ until the ash was carbon-free. From the ash solution, iron was determined by a spectrophotometric method and sodium choride was determined by a titrimetric method with silver nitrate solution. On the basis of the atomic weights of sodium and chloride, the results of sodium chloride were divided by 2.5 to convert salt to sodium. The carbohydrate content was determined by difference. The energy density was calculated by multiplying the protein and total carbohydrate content by $17 \mathrm{~kJ}$ ( $4 \mathrm{kcal}$ ) and adding the result to the fat content multiplied by $38 \mathrm{~kJ}$ ( $9 \mathrm{kcal})$.

\section{Estimating the nutrient intake}

According to the Brazilian School Meal Programme ${ }^{(10)}$, in primary public schools meals must provide at least $15 \%$ of children's daily nutritional needs. Private schools are not subject to any specific legislation.

The dietary reference values used to assess the foods available at the schools are summarised in Box 1.

The results obtained from each sample were added together and averaged to calculate the nutritional composition of the portions. The portion sizes at the public 
school were recommended by the nutritionist. At the private school, the food samples were weighed in the laboratory and the average was calculated to determine the portion sizes.

Means of the energy recommendation for male and female schoolchildren were used for comparison with other school meals programmes. Macronutrients in each portion, expressed as a percentage of the dietary recommendations of energy for children, taking into account the children's ages and that school foods must provide $15 \%$ of the daily needs, were compared with the Dietary Reference Intakes guidelines ${ }^{(13)}$ for the acceptable macronutrient distribution ranges (AMDR).

\section{Statistical analyses}

Statistical analyses were undertaken using the software Sigma Stat for Windows version 2.0 (1997; SPSS Inc., Chicago, IL, USA). The $t$ test was used to compare the

\section{Box 1 Dietary reference values per meal}

\begin{tabular}{lll}
\hline & \multicolumn{2}{c}{$15 \%$ daily intake } \\
\cline { 2 - 3 } & $7-8$ years & $9-10$ years \\
\hline Energy $(\mathrm{kcal})^{*}$ & 195 & 255 \\
Iron $(\mathrm{mg}) \dagger$ & $1 \cdot 5$ & $1 \cdot 2$ \\
Salt $(\mathrm{g}) \ddagger$ & $0 \cdot 75$ & $0 \cdot 75$ \\
Sodium $(\mathrm{g}) \S$ & $0 \cdot 18$ & $0 \cdot 23$ \\
\hline
\end{tabular}

$1 \mathrm{kcal}=4.184 \mathrm{~kJ}$.

*Energy: 4-8 years: male $=1400 \mathrm{kcal} / \mathrm{d}$, female $=$ $1200 \mathrm{kcal} / \mathrm{d} \quad($ mean $=1300 \mathrm{kcal} / \mathrm{d}$; American Heart Association et al. $\left.{ }^{(12)}\right)$; 9-13 years: male $=1800 \mathrm{kcal} / \mathrm{d}$, female $=1600 \mathrm{kcal} / \mathrm{d}($ mean $=1700 \mathrm{kcal} / \mathrm{d})$.

tRecommended dietary allowances - iron: 4-8 years $=10 \mathrm{mg} / \mathrm{d}$; 9-13 years $=8 \mathrm{mg} / \mathrm{d}^{(13)}$.

¥Salt: $7-10$ years $=$ maximum $5 \mathrm{~g} / \mathrm{d}$ (Scientific Advisory Committee on Nutrition $\left.{ }^{(14)}\right)$.

§Adequate intake - sodium: $4-8$ years $=1 \cdot 2 \mathrm{~g} / \mathrm{d}$; 9-13 years $=1.5 \mathrm{~g} / \mathrm{d}^{(13)}$. nutrient content of the foods according to the type of school. When data failed the normality test, the non-parametric Mann-Whitney test was used. The $\chi^{2}$ test was used to compare the proportions of samples that fell in the intervals proposed by the AMDR. When statistically different, the partition was used to identify in which categories the differences were present. Mean, standard deviation and coefficient of variation were calculated for portion sizes and nutrient content of the foods. The level of significance was $P<0 \cdot 05$.

\section{Results}

The analytical results of the foods available for primaryschool children are shown in Table 1 . The protein, lipid, iron and sodium contents and the energy values of the foods provided at the private school were significantly higher than those provided at the public school. Foods at the private school contained significantly less water. No differences were seen in the carbohydrate and salt values.

Tables 2 and 3 present the nutritional composition of the individual portions of food prepared at the public and private school, respectively. Two public school dishes (polenta and beans; chocolate milk and salt cookie) were either low or high in energy. Prepared foods in private school were, in general, energy-dense, particularly the hot dog with potato chips, which had high sodium content.

Figure 1 shows the mean percentage of the dietary reference values provided by prepared foods at the public and private schools, for children aged 7-8 and 9-10 years, respectively. For energy and iron, the recommendations are the minimum; for salt and sodium, the recommendations are the maximum. In both public and private schools, foods provided the minimum for energy and for iron. Intakes of salt were over twice the recommended amount, and for sodium they were over three times the recommended amounts, in both public and private schools.

The number and percentage of samples that fell in the intervals of the AMDR are presented in Table 4. Samples inconsistent with the AMDR were more likely to have exceeded the upper end of the range than to have fallen

Table 1 Nutrient content of the foods available for primary-school children according to the type of school

\begin{tabular}{|c|c|c|c|c|c|}
\hline \multirow[b]{2}{*}{ Nutrients } & \multicolumn{2}{|c|}{ Public (n 20) } & \multicolumn{2}{|c|}{ Private ( $n$ 25) } & \multirow[b]{2}{*}{$P$} \\
\hline & Mean or median & SD or P25-P75 & Mean or median & SD or P25-P75 & \\
\hline Water $(\mathrm{g} / 100 \mathrm{~g})$ & $65 \cdot 0$ & $7 \cdot 7$ & $47 \cdot 2$ & $4 \cdot 7$ & $<0.001^{*}$ \\
\hline Energy (kcal/100 g) & $155 \cdot 0$ & $33 \cdot 1$ & $249 \cdot 0$ & $23 \cdot 3$ & $<0.001^{*}$ \\
\hline$(\mathrm{kJ} / 100 \mathrm{~g})$ & 649 & 139 & 1046 & 98 & \\
\hline Protein $(\mathrm{g} / 100 \mathrm{~g})$ & $5 \cdot 0$ & $4 \cdot 0-5 \cdot 3$ & $11 \cdot 4$ & $9 \cdot 6-13 \cdot 3$ & $<0.001 \dagger$ \\
\hline Fat $(\mathrm{g} / 100 \mathrm{~g})$ & $4 \cdot 2$ & $1 \cdot 6$ & $9 \cdot 6$ & $1 \cdot 2$ & $<0.001^{*}$ \\
\hline Carbohydrate $(\mathrm{g} / 100 \mathrm{~g})$ & $29 \cdot 5$ & $26 \cdot 2-34 \cdot 3$ & $25 \cdot 0$ & $18 \cdot 4-28 \cdot 4$ & $0 \cdot 115 t$ \\
\hline Iron $(\mathrm{mg} / 100 \mathrm{~g})$ & $2 \cdot 1$ & $1 \cdot 3-2 \cdot 8$ & 3.8 & $3 \cdot 1-4 \cdot 0$ & $<0.001 \dagger$ \\
\hline Salt $(\mathrm{g} / 100 \mathrm{~g})$ & $1 \cdot 1$ & 0.4 & $1 \cdot 4$ & 0.4 & $0.012^{*}$ \\
\hline Sodium $(\mathrm{g} / 100 \mathrm{~g})$ & 0.4 & $0 \cdot 1$ & 0.6 & 0.2 & $0.007^{*}$ \\
\hline
\end{tabular}

${ }^{*} t$ test, mean and SD.

+Mann-Whitney test, median and 25th-75th percentiles. 
Table 2 Nutritional composition of the individual portions in the public school prepared foods

\begin{tabular}{|c|c|c|c|c|c|c|c|c|}
\hline Food & $\begin{array}{l}\text { Weight } \\
\text { (g) }\end{array}$ & $\begin{array}{l}\text { Energy } \\
\text { (kcal/kJ) }\end{array}$ & Protein (g) & Fat (g) & $\begin{array}{l}\text { Carbo- } \\
\text { hydrate } \\
\text { (g) }\end{array}$ & $\begin{array}{l}\text { Iron } \\
\text { (mg) }\end{array}$ & Salt (g) & $\begin{array}{c}\text { Sodium } \\
\text { (g) }\end{array}$ \\
\hline $\begin{array}{l}\text { Rice, beans, vegetables, } \\
\text { meat and dessert }\end{array}$ & 165 & $267 / 1118$ & $7 \cdot 6$ & $7 \cdot 3$ & $42 \cdot 7$ & 3.5 & $1 \cdot 8$ & 0.7 \\
\hline $\begin{array}{l}\text { Rice, vegetables and } \\
\text { meat }\end{array}$ & 155 & $220 / 921$ & 8.7 & $7 \cdot 2$ & $30 \cdot 0$ & $2 \cdot 5$ & $2 \cdot 0$ & 0.8 \\
\hline Pasta, meat and dessert & 180 & $371 / 1553$ & $7 \cdot 7$ & 5.9 & $71 \cdot 8$ & $4 \cdot 0$ & $1 \cdot 3$ & 0.5 \\
\hline Polenta and beans & 120 & $121 / 507$ & 6.4 & 3.4 & $16 \cdot 2$ & $4 \cdot 7$ & 1.6 & 0.6 \\
\hline Rice pudding & 120 & $180 / 754$ & 3.0 & $2 \cdot 6$ & $36 \cdot 1$ & 1.6 & 0.2 & 0.1 \\
\hline Chocolate milk and salt & 195 & $348 / 1457$ & 9.8 & 9.8 & $55 \cdot 2$ & $4 \cdot 1$ & $1 \cdot 2$ & 0.4 \\
\hline
\end{tabular}

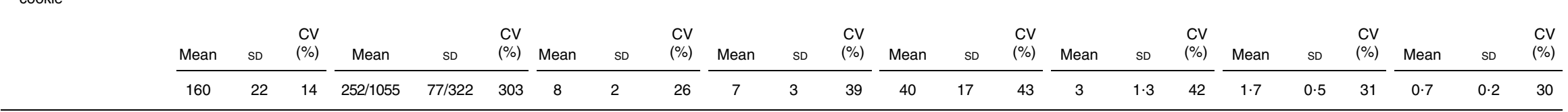

Table 3 Nutritional composition of the individual portions in the private school prepared foods

\begin{tabular}{|c|c|c|c|c|c|c|c|c|c|c|c|c|c|c|c|c|c|c|c|c|c|c|c|c|}
\hline Food & & $\begin{array}{l}\text { Weight } \\
\text { (g) }\end{array}$ & & & $\begin{array}{l}\text { Energy } \\
\text { (kcal/kJ) }\end{array}$ & & & Protein (g) & & & Fat (g) & & & $\begin{array}{l}\text { Carbo- } \\
\text { hydrate } \\
\text { (g) }\end{array}$ & & & $\begin{array}{l}\text { Iron } \\
(\mathrm{mg})\end{array}$ & & & Salt (g) & & & $\begin{array}{c}\text { Sodium } \\
\text { (g) }\end{array}$ & \\
\hline Chicken sfiha (meat pie) & & 120 & & & $325 / 1361$ & & & $14 \cdot 6$ & & & $12 \cdot 1$ & & & $39 \cdot 3$ & & & $5 \cdot 4$ & & & $1 \cdot 4$ & & & 0.6 & \\
\hline $\begin{array}{l}\text { Sandwich (ham, cheese, } \\
\text { tomato and oregano) }\end{array}$ & & 140 & & & $384 / 1608$ & & & $14 \cdot 6$ & & & $14 \cdot 8$ & & & $48 \cdot 1$ & & & $5 \cdot 9$ & & & $1 \cdot 3$ & & & 0.5 & \\
\hline $\begin{array}{l}\text { Pizza - slice (cheese, } \\
\text { ham, tomato and } \\
\text { oregano) }\end{array}$ & & 120 & & & $309 / 1294$ & & & 14.5 & & & $11 \cdot 8$ & & & $36 \cdot 1$ & & & $4 \cdot 6$ & & & $1 \cdot 8$ & & & 0.7 & \\
\hline \multirow{3}{*}{$\begin{array}{l}\text { Breaded chicken skewer } \\
\text { Hot-dog with potato } \\
\text { chips and canned } \\
\text { sweet corn }\end{array}$} & & 50 & & & $211 / 883$ & & & $11 \cdot 6$ & & & $16 \cdot 8$ & & & $3 \cdot 3$ & & & 0.9 & & & 0.8 & & & 0.3 & \\
\hline & Mean & SD & $\begin{array}{l}\mathrm{CV} \\
(\%)\end{array}$ & Mean & SD & $\begin{array}{l}\mathrm{CV} \\
(\%)\end{array}$ & Mean & SD & $\begin{array}{l}\mathrm{CV} \\
(\%)\end{array}$ & Mean & SD & $\begin{array}{l}\mathrm{CV} \\
(\%)\end{array}$ & Mean & SD & $\begin{array}{l}\mathrm{CV} \\
(\%)\end{array}$ & Mean & SD & $\begin{array}{l}\mathrm{CV} \\
(\%)\end{array}$ & Mean & SD & $\begin{array}{l}\mathrm{CV} \\
(\%)\end{array}$ & Mean & SD & $\begin{array}{l}\mathrm{CV} \\
(\%)\end{array}$ \\
\hline & 135 & 57 & 43 & $336 / 1407$ & $131 / 548$ & 393 & 15 & 2 & 12 & 13 & 6 & 45 & 39 & 19 & 49 & 5 & 3 & 53 & 2 & $1 \cdot 3$ & 68 & 0.8 & 0.5 & 69 \\
\hline
\end{tabular}


below the lower end. There were significantly more samples from the private school with a fat content as a percentage of energy above 35\%, when compared with samples from the public school, for children aged both 7-8 and 9-10 years. For protein (as a percentage of energy), there were significantly more samples from the private school that fell in the interval above $30 \%$, when considering only children aged $7-8$ years. There were no statistically significant differences for the carbohydrate intervals.

\section{Discussion}

In the present study, $77 \%$ of the children in public school participated in the School Meals Programme at least three times a week. This attendance was higher than in a Brazilian national study $(46 \%)^{(15)}$ and the US School Meals Program $(62 \%)^{(16)}$, but lower than that observed in British children

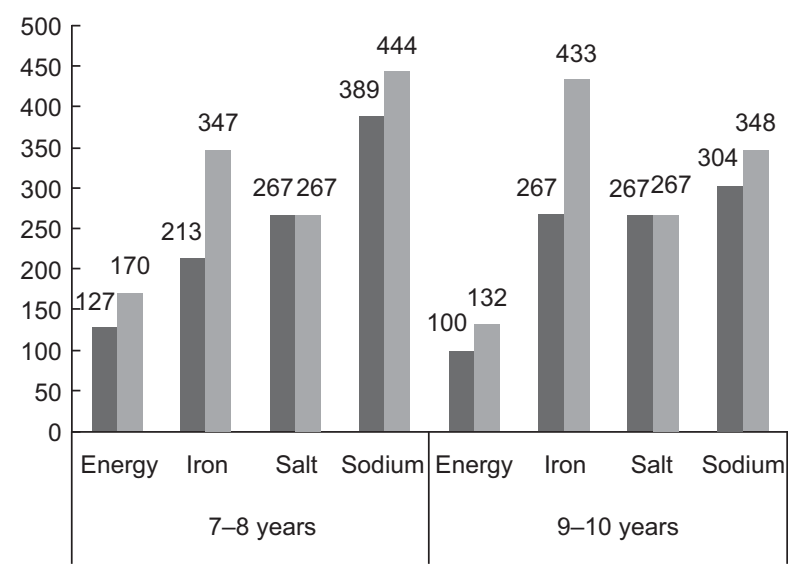

Fig. 1 Percentage of the dietary reference values (see Box 1) in the individual portions of foods prepared at the public $(\square)$ and private $(\square)$ school, taking into account the age of the children eligible for free meals (85\%) ${ }^{(17)}$. At the private school, $53 \%$ of the children consumed foods available at the cafeteria at least three times a week. At the public school, $22 \%$ of the children consumed foods from the cafeteria with the same weekly frequency. The percentages, at both the public and private school, were considerably higher than that of US children (19\%) who consumed snacks at cafeterias located in public schools ${ }^{(3)}$.

Dietary assessment methods to estimate nutrient intake have a number of possible limitations, such as estimation of the portion sizes in grams and the unavailability of a valid food composition table. In our study, we used the duplicate food collection method, which is considered to be the method that best overcomes these constraints and has greater accuracy ${ }^{(18)}$. In addition, the sampling of the foods covered a considerable period of time: a month of the planned menus followed by all public schools and the foods sold at the private school. Thus, the results expressed the actual composition of foods as they were consumed by the schoolchildren.

Unlike American and British public school meals programmes, the Brazilian Programme is universally free of charge and all children in public schools are eligible. Another difference is that the daily menus have only one option of dish, meaning that children do not have food choices. Public schools must provide $15 \%$ of the children's daily needs and must stimulate healthy eating habits. The legislation does not apply to private schools.

The public schools had a selection of healthy food items comprising meat, cereals, vegetables and fruits. They provided less energy, protein and fat, and likely less salt and sodium, and showed more equilibrated macronutrient distribution ranges, especially in those foods intended for 7-8-year-old children. However, there was a wide variability in the energy and nutrient content during weekdays even though the portion size did not vary much. Some portion

Table 4 Distribution of the number and percentage of samples in the intervals of the acceptable macronutrient distribution ranges, taking into account the children's age and that school meals must provide $15 \%$ of the daily requirements

\begin{tabular}{|c|c|c|c|c|c|c|c|c|c|c|}
\hline \multirow[b]{3}{*}{ Acceptable macronutrient distribution ranges } & \multicolumn{5}{|c|}{$7-8$ years } & \multicolumn{4}{|c|}{$9-10$ years } & \multirow[b]{3}{*}{$P$} \\
\hline & \multicolumn{2}{|c|}{ Public school } & \multicolumn{2}{|c|}{ Private school } & \multirow[b]{2}{*}{$P$} & \multicolumn{2}{|c|}{ Public school } & \multicolumn{2}{|c|}{ Private school } & \\
\hline & $n$ & $\%$ & $n$ & $\%$ & & $n$ & $\%$ & $n$ & $\%$ & \\
\hline \multicolumn{11}{|l|}{ Fat (percentage of energy) } \\
\hline$>35$ & 5 & 25 & 21 & 84 & & 1 & 5 & 16 & 64 & \\
\hline $25-35$ & 11 & 55 & 2 & 8 & $<0 \cdot 001^{*}$ & 10 & 50 & 5 & 20 & $<0.001 \ddagger$ \\
\hline$<25$ & 4 & 20 & 2 & 8 & & 9 & 45 & 4 & 16 & \\
\hline \multicolumn{11}{|l|}{ Protein (percentage of energy) } \\
\hline$>30$ & 0 & 0 & 10 & 42 & & 0 & 0 & 1 & 4 & \\
\hline $10-30$ & 19 & 95 & 15 & 60 & $0.004 t$ & 18 & 94 & 23 & 96 & 0.359 \\
\hline$<10$ & 1 & 5 & 0 & 0 & & 1 & 6 & 0 & 0 & \\
\hline \multicolumn{11}{|l|}{ Carbohydrate (percentage of energy) } \\
\hline$>65$ & 13 & 65 & 18 & 72 & & 8 & 40 & 12 & 48 & \\
\hline $45-65$ & 5 & 25 & 2 & 8 & $0 \cdot 240$ & 6 & 30 & 8 & 32 & $0 \cdot 730$ \\
\hline$<45$ & 2 & 10 & 5 & 20 & & 6 & 30 & 5 & 20 & \\
\hline
\end{tabular}

${ }^{*}$ Partition of $\chi^{2}:>35 \%$ private school.

tPartition of $\chi^{2}:>30 \%$ private school.

¥Partition of $\chi^{2}:>35 \%$ private school. 
sizes in the present study were comparable to similar meals in the $\mathrm{UK}^{(19)}$, i.e. rice, vegetables and meat $(155 \mathrm{~g}$ and $158 \mathrm{~g}$, respectively), rice pudding (120 $\mathrm{g}$ and $130 \mathrm{~g}$, respectively) and chocolate milk and salt cookie (195g and $210 \mathrm{~g}$, respectively). Portions sizes of pasta, meat and dessert (180 g and $225 \mathrm{~g}$, respectively) were less comparable. Wide variability of energy and nutrients was also seen in a study in Spain ${ }^{(20)}$. Even though the mean of the portion sizes in the present study was lower than that in a similar study in Brazil $^{(8)}$ (160g and $187 \mathrm{~g}$, respectively), the energy value was higher (1054 kJ (252 kcal) v. $791 \mathrm{~kJ}(189 \mathrm{kcal}))$ because the fat and carbohydrate values were higher $(6.7 \mathrm{~g} v .3 .2 \mathrm{~g}$ and $40.0 \mathrm{~g} v .32 \cdot 4 \mathrm{~g}$, respectively). In the USA and Spain ${ }^{(5,20)}$, school meals are more energy-dense, and in the $\mathrm{UK}^{(21)}$, they are similar to our results.

Examples of energy-dense, low-nutrient competitive foods in US public schools are sugar-sweetened beverages, salty/high-fat chips, high-fat baked foods, desserts, breakfast pastries, brownies, cookies and French fries ${ }^{(22)}$. Unlike snacks provided in the USA, those available at the private school, although energy-dense solid foods, were not of low nutritional value. They were energydense with regard to higher fat and protein content when compared to the prepared foods in public schools, even though the portion sizes were smaller. Nutrient values also showed a wider variation. The prepared foods in private school provided approximately $30 \%$ of the daily energy requirements even though they mostly did not constitute a meal. The finding that the hot dogs had a sodium content of $1.8 \mathrm{~g}$ is compelling because one single meal almost reached the daily upper intake limit for sodium $(1.9 \mathrm{~g} / \mathrm{d} \text { for children aged } 7-8 \text { years })^{(13)}$. This is even more important when considering that the sodium content assessed in the present study came only from the salt added to the foods.

Macronutrient ranges were more balanced in the meals provided at the public schools in relation to fat and protein. There were significantly fewer samples (25\% and $5 \%$ for 7-8-year and 9-10-year-old schoolchildren, respectively) with fat values above $35 \%$ as a percentage of energy, when compared to the prepared foods available at the private school. These values were also lower than those found in a similar Brazilian study, where 36\% of the samples exceeded the upper limit of fat and protein $^{(23)}$. In all, 38\% of the lunches offered at US elementary public schools had fat values above $35 \%$ as a percentage of energy ${ }^{(5)}$, less than those found at the private school in the present study (84\% and 64\%, for 7-8- and 9-10-year-old schoolchildren, respectively). None of the samples of the meals provided by public schools for schoolchildren aged 7-8 and 9-10 years were found to have protein values above $30 \%$ as a percentage of energy. For carbohydrates, the majority of the samples fell above the upper limit.

Unlike those meals offered in the USA and the UK, foods prepared at the public school met energy and iron requirements according to Brazilian legislation. In the USA approximately $20 \%$ of the elementary public schools did not meet the standards for energy ${ }^{(5)}$. In the UK the mean energy intake was $1840 \mathrm{~kJ}$ ( $440 \mathrm{kcal}$ ), just below the government standard of $2218 \mathrm{~kJ}(530 \mathrm{kcal})^{(24)}$. In the case of iron, $5 \%$ of US elementary schools did not meet the standards ${ }^{(5)}$, whereas in the UK the mean intake was $1.8 \mathrm{mg}$ instead of the recommended $3.0 \mathrm{mg}^{(24)}$. The positive results in the present study may be attributed to the Brazilian Programme's method of fortifying wheat and cornflour with a mandatory minimum of $4 \cdot 2 \mathrm{mg}$ of iron per $100 \mathrm{~g}^{(25)}$.

The most impressive result in the present study is the high sodium content in the prepared foods available at schools. This content was alarmingly high. As a percentage of the dietary reference values, the sodium content was approximately four and three times the recommended values for children aged 7-8 and 9-10 years, respectively. This finding is in line with the dietary preference of the Brazilian population for high sodium intake, which is more than twice the recommended daily level ${ }^{(26)}$. The sodium content from prepared foods in the public school was lower in the USA and the UK (80\% and 10\% above the reference values, respectively) ${ }^{(5,24)}$. These findings are worrying since a significant association between salt intake and systolic blood pressure was found in a study with children and adolescents ${ }^{(27)}$. High salt intake may predispose schoolchildren to develop high blood pressure later in life ${ }^{(28)}$.

Overall, prepared foods at the public school were of better nutritional quality than those at the private school and the school meals offered in some developed countries. However, corrective action is needed to address the wide variability in energy and nutrient content during weekdays and in the sodium content of the culinary preparations. At the private school, the children were free to choose their foods, so that theoretically they would choose the same food on all weekdays. Furthermore, private schools are not bound by legislation and are therefore free to sell the foods they choose. In addition, the availability of other foods at the schools - whether public or private - allows schoolchildren to buy and eat high fat, sugar/salt snacks. Considering that when given the choice children choose less healthy options ${ }^{(21)}$, stricter standards should be put in place for nutritionists, caterers, teachers, children and parents to ensure that schoolchildren eat more healthily.

The better nutritional quality of the prepared foods at the public school when compared to those at the private school and to the public school meals offered in some developed countries can probably be explained by the fact that a nutritionist, as required by law, was responsible for planning the menus at the public schools. The involvement of dietetic expertise when designing meals was linked to better dietary balance of meals in France ${ }^{(29)}$. Even though both the USA and the UK have advisory 
committees on nutrition, it is unclear who is in charge of implementing the recommendations at schools. Further studies are necessary to investigate the impact that nutritionists may have on implementing and managing school meals programmes.

Some limitations of the present study must be acknowledged. It was conducted in only one city and at one private school. Therefore, the results might not be generalised to the entire country, even though all public school meals programmes must follow the same legal requirements. Indeed, all the free meals served at public schools may be the same (in a given city), but only one private school was surveyed, and other private schools may serve healthier foods in their cafeteria.

However, to our knowledge, this is the only study in which the nutritional quality of the foods available in private school has been evaluated. The strengths of the study include the duration of sampling the prepared foods, which covered a month of the planned menus provided by all public schools and the prepared foods sold at the private school, and the results expressed the actual composition of foods as they were consumed by the schoolchildren.

The present study provides information of public health relevance and supports the need for public policies to improve the school food environment. Continued changes to school food environments and practices, together with nutritional education for children and parents, are essential. Improving the food options available at school will make it easier for children to select healthy meals. Food and nutrition professionals working with schools can promote and provide nutritional education to children to encourage them to select more healthy foods, both at school and in other situations. Making healthy food choices is an essential part of a healthy lifestyle that will prevent future negative health consequences in adulthood.

\section{Acknowledgements}

This research received no specific grant from any funding agency in the public, commercial or not-for-profit sectors. The authors state that there are no conflicts of interest. M.L.W. participated in conception and design of the study, in acquisition, analysis and interpretation of data, and in drafting the manuscript; T.B.M. participated in conception and design of the study, in analysis and interpretation of data, and in revising the manuscript, and has given final approval for this version to be published. All authors read and approved the final manuscript.

\section{References}

1. Ministério de Educação (2009) Fundo Nacional de Desenvolvimento da Educação. Alimentação Escolar. http://www.fnde. gov.br/home/index.jsp?arquivo=alimentacao_escolar.html (accessed July 2009).

2. Clark MA \& Fox MK (2009) Nutritional quality of the diets of US public school children and the role of the school meal programs. J Am Diet Assoc 109, Suppl. 1, S44-S56.

3. Fox MK, Gordon A, Nogales R et al. (2009) Availability and consumption of competitive foods in US public schools. J Am Diet Assoc 109, Suppl. 1, S57-S66.

4. Condon EM, Crepinsek MK \& Fox MK (2009) School meals: types of foods offered to and consumed by children at lunch and breakfast. J Am Diet Assoc 109, Suppl. 1, S67-S78.

5. Crepinsek MK, Gordon AR, McKinney PM et al. (2009) Meals offered and served in US public schools: do they meet nutrient standards? J Am Diet Assoc 109, Suppl. 1, S31-S43.

6. Padovani RM, Lima DM, Colugnati FAB et al. (2007) Comparison of proximate, mineral and vitamin composition of common Brazilian and US foods. J Food Compost Anal 20, 733-738.

7. Ribeiro P, Morais TB, Colugnati FAB et al. (2003) Food composition tables: laboratory comparative analysis. Rev Saude Publica 37, 216-225.

8. Flavio EF, Barcelos MFP, Cirillo MA et al. (2008) Evaluation of school meals offered to elementary students of municipal schools of Lavras, MG. Cienc Agrotec 32, 1879-1887.

9. Índice de Desenvolvimento Humano (not dated) Atlas do Desenvolvimento Humano no Brasil. Municípios do Brasil. http://www.pnud.org.br/atlas/ranking/IDH-M\%2091\%2000 $\% 20$ Ranking $\% 20$ decrescente $\% 20$ (pelos $\% 20$ dados $\% 20$ de $\%$ 202000).htm (accessed July 2009).

10. Ministério de Educação (2006) Fundo Nacional de Desenvolvimento da Educação. Alimentação Escolar. Normas para Execução do Programa Nacional de Alimentação Escolar. ftp://ftp.fnde.gov.br/web/resolucoes_2006/res032_ 10082006.pdf (accessed July 2009).

11. Association of Official Analytical Chemists (AOAC) (2003) Official Methods of Analysis of AOAC International, 17th ed. Virginia: AOAC Inc.

12. American Heart Association, Gidding SS, Dennison BA et al. (2006) Dietary recommendations for children and adolescents: a guide for practitioners. Pediatrics 117, 544-559.

13. Institute of Medicine, Food and Nutrition Board (2000) Dietary Reference Intakes: Applications in Dietary Assessment. Washington, DC: National Academies Press.

14. Scientific Advisory Committee on Nutrition (2003) Salt and Health. London: The Stationery Office; available at http:// www.sacn.gov.uk/pdfs/sacn_salt_final.pdf

15. Sturion GL, Silva MV, Ometto AMH et al. (2005) Conditioning factors of students participation in the Brazilian School Meal Program. Rev Nutr 18, 167-181.

16. Briefel RR, Crepinsek MK, Cabili C et al. (2009) School food environments and practices affect dietary behaviors of US public school children. J Am Diet Assoc 109, Suppl. 1, S91-S107.

17. Nelson M, Nicholas J, Suleiman S et al. (2006) Meals in Primary Schools in England. London: King's College London; available at http://www.dcsf.gov.uk/research/ data/uploadfiles/RR753.pdf

18. Welch AA (2005) Dietary intake measurement: methodology. In Encyclopedia of Human Nutrition, 2nd ed., vol. 2, pp. 7-16 [B Caballero, L Allen and A Prentice, editors]. Oxford: Elsevier.

19. Davies OH, Suleiman S, Nicholas J et al. (2008) Food portions weights in primary and secondary school lunches in England. J Hum Nutr Diet 21, 46-62.

20. Diaz JC, Alvarez CR, Pacheco MC et al. (2008) Assessment of the nutritional value of the menus served in school 
canteens on the Island of Tenerife, Spain. Nutr Hosp 23, $41-45$.

21. Nelson M, Lowes K, Hwang V et al. (2007) The contribution of school meals to food consumption and nutrient intakes of young people aged 4-18 years in England. Public Health Nutr 10, 652-662.

22. Briefel RR, Wilson A \& Gleason PM (2009) Consumption of low-nutrient, energy-dense foods and beverages at school, home, and other locations among school lunch participants and nonparticipants. J Am Diet Assoc 109, Suppl. 1, S79-S90.

23. Domene SMA, Pereira TC \& Arrivillaga RK (2008) Estimated zinc availability in school meals done with standard foods in the city of Campinas (SP), Brazil. Rev Nutr 21, 161-167.

24. Rees GA, Richards CJ \& Gregory J (2008) Food and nutrient intakes of primary school children: a comparison of school meals and packed lunches. J Human Nutr Diet 21, $420-427$.
25. Agência Nacional de Vigilância Sanitária (2002) Regulamento Técnico para a Fortificação das Farinhas de Trigo e das Farinhas de Milho com Ferro e Ácido Fólico. http:// e-legis.anvisa.gov.br/leisref/public/showAct.php?id=1679\& word $=$. (accessed July 2009).

26. Sarno F, Claro RM, Levy RB et al. (2009) Estimated sodium intake by the Brazilian population, 2002-2003. Rev Saude Publica 43, 219-225.

27. He FJ, Marrero NM \& MacGregor GA (2008) Salt and blood pressure in children and adolescents. J Hum Hypertens 22, 4-11.

28. Lauer RM \& Clarke WR (1989) Childhood risk factors for high adult blood pressure: the Muscatine Study. Pediatrics 84, 633-641.

29. Dubuisson C, Lioret S, Calamassi-Tran G et al. (2009) School meals in French secondary state schools with regard to the national recommendations. Br J Nutr 102, 293-301. 